\title{
The Level of Applying Ergonomic Factors in Work Environment at the World Islamic Sciences University and Its Influence on Decreasing Management Problems from the Perspective of Staff Members
}

\author{
Mohammed Falah Ali Khawaldeh ${ }^{1}$ \\ ${ }^{1}$ Curriculum and Instruction Department, The World Islamic Education and Sciences University, Jordan \\ Correspondence: Mohammed Falah Ali Khawaldeh, Curriculum and Instruction Department, The World Islamic \\ Education and Sciences University, Jordan. E-mail: m.khawaldeh64@yahoo.com
}

Received: April 1, 2019

Accepted: April 28, 2019

Online Published: May 30, 2019

doi:10.5539/mas.v13n6p 75

URL: https://doi.org/10.5539/mas.v13n6p75

\begin{abstract}
This study aims to unravel the level of applying ergonomics, and its influence on decreasing management problems in work environments at the World Islamic Sciences University, henceforth (WISE U.), from the perspective of staff members. To achieve the goals of the study, the descriptive method was adopted. Sample of the study consisted of (94) staff members.

Two questionnaires were designed: the first is on ergonomics which consisted of four dimensions: the human, the structural and the technical and technological. The second questionnaire was on decreasing management problems. The results revealed that staff members assessment for ergonomics with all its dimensions was medium, while their assessment for decreasing management problems was high.

It was also found, from the perspective of staff members, that applying ergonomics with the purpose of decreasing management problems in the university was high, excluding the application of technical dimension.
\end{abstract}

Keywords: ergonomics, management problems, World Islamic Sciences University, staff members

\section{Introduction}

Nowadays, educational institutions face great challenges in the wake of an astounding scientific and technological revolution that requires a distinguished management which conforms to the changes affecting all fields of life. This can be achieved through the management adaptation to the new developments in all fields of work. Changes in management of universities are systematic and based on plans known as ergonomics or ergonomic factors, human performance, or psychological engineering (Al-Ali, 2004).

Ergonomics is known to be the science that is concerned with human body, its potentials and the qualities relevant to equipment design, machinery, systems, functions and work environments by which humans can achieve a safe and effective use (Kumru \& Kihcogulari, 2008:1). Slack, 2004: 286) defines it as "a method of work design that depends on some psychological human resources and their suitability to work melieu". (Evans \& Colier, 2007: 332) define it as the method concerned with improving productivity and safety through work design, equipment, work place, taking into consideration the physiological qualities of workers.

The researcher sees that ergonomics creates drastic changes in the management of human resources on the structural level by reconstructing administration via workgroups; at the technical level, by redesigning operations of this management to get rid of extra activities and concentrate on strategic ones; at the technological level it switches to electronic management; at the human level, it employs human resources and gets rid of administrative and routine tasks they perform.

If the essence of engineering is value creation, the essence of ergonomics is increasing the value for the producer or the user. Ergonomics restructuring is a pre-programmed attempt to highly estimate the value of human resources. This is not limited to restructuring and reforming knowledge content and human capital skills and using it for the interest of the institution, but trespasses that to redesign instruments to consolidate the capability and competition of the institution, in addition to the methods of redesigning and forming human capital in the organization (khan, 2015:37).

Ergonomics differs from traditional methods of development. It is a process that begins from naught and highly 
concentrates on activities and is concerned with results and the need of service receptor. It is based on restructuring the process in to to. One of its qualities is that it starts with skepticism regarding the whole management process and may sometimes need change, rebuilding or nullification (Al-Sultan, 2001).

Ergonomics might occur at large or narrow dimensions. At the large dimension, the need for the whole work or getting away with it, should be reconsidered.

If something can be done, it should be done in the institution by the employees or should a foreign party be hired to reconstruct if deemed necessary or strategic (Abu Awad, 2015). Khan (2012) thus, sees that engineering of human resources depends on the following three basic substitutes:

1. Getting rid with the low-value activities and services so as to save time and money spent in restructuring work engineering, products, and services not needed for the organization

2. Assigning services and activities to external parties that might provide low-cost and better-quality offers by which the organization secures low costs and better quality. Consequently, allows human resources management to work with more strategic activities and to play an active and basic role.

3. Redesigning activities of high strategic significance which might not be assigned to foreign parties who should not take any part in the strategic issues or in essential competency. It is noted that the most significant source of competitive quality of any institution is human resources.

Restructuring engineering of human resources may be done at a lower level through a radical redesigning and using information technology that include all types of personal calculators and developed smart phones used by competent employees authorized to provide services to the clients or to themselves in order to achieve fundamental high quality improvements (Al-Shibli \& Al-Nsour, 2009).

Studies of (Dagher and Al-Qudah 2015, Khan, 2015 \& Abu Awad, 2015) are alike with regard to the dimensions of Ergonomics. In general, they are four which the researcher adopted in his questionnaire. The dimensions are: human, structural, technical, and performance.

Ergonomics passes through the following three basic stages:

First stage:

Getting rid of all routine administrative and paper work, conducting all works pertaining human resources through personal computers (Al-Shibly \& Nsur, 2009).

Second stage:

Adopting a short cut method to develop systematic fast-service. Many services like (Private counseling for choosing suitable training courses through specialized machines available at offices of human resources) may be offered. This implies developing machines and programs that offer services to human resources upon request, especially to the nearest beneficiaries (Mahmood 2013).

Third stage:

Developing information systems of executives pertaining strategic planning. These systems need to be developed to improve strategic planning regarding recruitment, training, motivation, and achieving competitive levels necessary for re-engineering (Farhat, 2011).

Management problems vary in universities which attempt to mitigate such problems through conducting studies on the problems they encounter in order to discover them and put suitable solutions. Problems are of different types: some are linked to funding and securing necessary needs to realize university vision and mission in the light of the strategic plans that have been designed; other problems are related to facilities, classrooms, and capacity of absorption. Competitive quality might be related to availability and quality of academicians, their experience, level of training, readiness to improve performance, or job satisfaction.

Universities represent a large organizational structure that includes scientific sections, several management units which usually perform their duties to run the technical and management duties according to one's specialization and responsibilities on campus or off campus (Al-Nueimi, 2006). This kind of organizational structure results in several different problems regarding level and nature.

Al-Juboori (2000) defined the problem to be a deviation or disequilibrium between what is and what might be, i.e., the problem is an undesired result. While (Shams Eddin, 2005:11) defines it as a realistic case manifested in the system's inability to perform its functions and achieve its objectives. It thus, needs diognization, analysis, and requires a solution. 
A management problem is that related to management which doesn't function properly to achieve its goals, or might be that management system which doesn't conform to the desired present or future situation, or not found when the need for change is required (Shams Eddin, 2005:11). These are the difficulties the chairman encounters with regard to planning, organizing, and following up. These obstacles prevent the chairman from an ideal use of human power and primary resources in the department (Al-Shammari, 2005, 8).

The researcher sees that the management problem is the difficulties that hamper the system from functioning and achieving its goals. The researcher also sees that the important thing for the university is to analyze its situation with transparency and to examine the results in order to figure out how they affect other fields. It should not focus on the results, but concentrate on solving the problem itself by tracing the real factors behind it in order to know how it influences or be influenced by other problems. If there are problems which can't be solved collectively, then priority needs to be given to the foremost among them, according to the degree of affecting basic goals of the university and thus solve them in graduation.

Among the most significant problems in universities is what Al-yusuf (2012) mentioned: not equipping classrooms with equipment needed for the teaching process, bad air conditioning, lighting, cleanliness of classrooms, lack of references, disregarding academic competence in management posts, absence of conformity between administrators and academicians, and finally slow management functioning.

Al-Salem (2000) sees that one of the most dangerous management problems is that of motivation which might be caused by: its ambiguity to both administration and beneficiaries, lack of scientific and field studies associated with motives and intentions of employees, inaccurate assessment of performance due to personal feelings most of the time, and shortage of skillful managers to effect such motives.

Al-Duri (2003) sees that the most significant problems for organizations are strategic as manifested in: absence of objectives or criteria of quantitative performance and the inability of information system to present correct one at a suitable time.

One of the main studies on management problems in universities, ergonomics, and re-engineering, is that of Dagher and Al-Qudah (2016) which aimed to develop a pattern of human engineering of decision making regarding education in Jordanian universities. Sample of the study consisted of (523) administrative educators and academicians from Jordan university the academic year (2013-2014). The results showed that the assessment of sample members regarding educational decision making was high. The results also showed that there was a statistical difference in the extant process of decision making in the universities that might be attributed to the variable of work nature in favor of the dean. The study came up with a pattern to develop educational decision making in Jordanian universities.

Al-Taee's Study (2015) aimed to figure out management problems that encountered chairmen in Baghdad and Mustansireyah Universities to solve them out. The sample of the study consisted of (162) chairmen of academic departments. As represented by researcher in a questionnaire. The results showed that in some cases the problems were of high level, while in others were low. Such results might be referred back to: chairmen's weak follow-up, absence of will to have creative solutions, being satisfied with traditional general approach, and concentration, or implementing decisions without any discussion. The study also revealed weakness in determining performance criteria, being ambiguous for both instructors and administration. Weakness in having a clear vision and any relation with leadership were also clear.

Khan's study (2015) aimed to examine the direct effect of re-using ergonomics in improving human performance that was done through different dimensions: organizing human resources, using technology, redesigning processes of human resources, changing roles and qualifications of chairmen and instructors; measuring outcomes of highlevel performances represented in job-merging and rewarding on the basis of performance, and finally creative behavior. Two questionnaires were given to (115) employees of economic establishments in Baskara district. The results revealed that redesigning ergonomics had a direct impact on human performance achieved through changing roles and qualifications of first class chairmen and employees. The study also concluded that redesigning ergonomics with its dimensions of using information technology and reorganizing human resources indirectly influenced human performance, through high quality practices, which were the mediator in such relations.

Al-Amiri's study (2014) aimed to determine the most important problems staff members at colleges of education in Yemen encounter, besides the influence of: college variables, gender, specialization, academic degree, years of experience, and age on these problems. The researcher used the descriptive analytical method. The study population consisted of (204) staff members in faculties of education at Hudaideh and Omran. (147) members equal to (70.3\%) cooperated. To achieve goals of the study the researcher prepared a fivefold-graded questionnaire consisting of (61) paragraphs distributed into six domains. After conducting the study and completing statistical 
analyses, the results showed that the most serious problems were in: the domains of salaries and stimuli, education, work environment, policies, and practices of university administration respectively. Problems pertaining the domains of academic promotions and students were less serious. The results showed that there were differences with statistical significance in the fields of salaries, stimuli pertaining gender variable in favor of male instructors, but in the field of teaching problems regarding academic degree variable, it was in favor of instructors and TAs (teaching assistants). There were also differences in the field of academic promotions pertaining gender variable in favor of females. As for age variable, the differences found were in favor of those who were younger than 30 and those between 30-39 years of age.

(Ensem, Moorthy \& Setegn, 2013) conducted a study which aimed at evaluating engineering of practical works on organizational performance. It is a case study on the economic financial and developmental bureau in Ethiopia. The study sample comprised (80) officials from the bureau and office clients. The study concluded that clients were satisfied with fast service, service quality, and time cycle. But there was no criterion to evaluate the performance of employees in the office. In addition, they were not given any privilege regarding salary, indemnity, promotion and tenurship. Based on results of the study, work re-engineering became a useful means for any organization seeking for the improvement of performance of its present structure and planning to achieve the structural goal. The study confirmed that re-engineering processes were an active instrument for the organizations seeking for proficiency.

(Erraha, oubedda, \& khalfaoui, 2012) conducted a study whose aim was to develop an information system to help in university decision making. The system was based on the relation between functional parties and their activities. In addition, the study also aimed at enabling decision makers and university directors to obtain valuable information to which they refer back in decision taking. The study adopted the qualitative method and surveyed decision taking in universities. It ended up with designing a handy data base from which facilitate decisions taking by university decision makers.

Al-Muzayyan study (2015) aimed at determining academic and management problems at Islamic university in Gaza from the perspective of staff members. To achieve its goals, the researcher used the descriptive analytical method. The study sample comprised (104) staff members from Islamic University at Gaza. The study found that there were academic and management problems with more than $50 \%$, in addition to differences with statistical significance between the evaluation means of staff members with regard to academic rank and management problems associated with faculty variable in favor of applied sciences, in academic rank in favor of assistant or associated professors; in the variable of years of experience, in favor of less than four years. It also found that there were no differences with statistical significance between staff evaluation means for academic and management problems attributed to age variable of staff members.

Al-Suroor and Al-Zoubi (2009) conducted a study that aimed to determine academic problems staff members at Al-Albeit University encounter. The descriptive analytical method was adopted. Population of the study and sample comprised all university staff members. To achieve the goal, the two researchers developed a questionnaire of (35) items. The study was applied to a (96) - member sample. The results showed that the severest problems were in those related to students and promotion, and the least were those related to administration. It also found that there were no differences with statistical significance between academicians with different ranks regarding student problems, staff members, and administration, but there were differences with statistical significance between different academic ranks, in scientific research and promotion in favor of higher ranks.

There were no differences with statistical significance pertaining the number of years of experience in all fields. The study of (Gmelch \& Parkay, 1999) aimed to analyze management problems new chairmen of academic departments in American universities encounter. Sample of the study comprised (13) new chairmen purposively selected from ten universities and from private and public colleges of eight American states.

Direct observation and self-assessment were the instruments used to determine the objectives of the study. The results showed that the new chairmen encountered different problems ranging from severe to mild in switching to the new positions. Some of those problems emerged from: counter roles or ambiguity of the role played by the chairman, turning the individual administrative type to the social one, switching from books to handouts, from centrality to decentralization, from stability to movability, and from being a client to being an agent. After reviewing previous studies, we noticed that: they tackled administration and human re-engineering; that some of them tried to find solutions for management problems staff members encounter, that their samples were selected from staff members and employees in different institutions, and that most of them used questionnaires to collect data.

This study conforms to the previous ones in that it tackled ergonomics and management problems in universities, 
but it is distinguished for discussing the level of applying ergonomics in work environment in World University for Islam Sciences, henceforth, (WISE U.) and its influence in decreasing management problems from the perspective of staff members.

As (WISE U.) has been recently instituted, and as it always attempts to adopt what is new in teaching methods and management, the researcher found that it is worthy to conduct his research regarding these issues in it.

The university was instituted in compliance with decree no. (16) in 2008 according to which the university has been given an administrative and financial independence and has the right to use mobile and immobile funds in order to achieve its objectives within the framework of Al-Bait ideology whose aim is to introduce Islamic culture and morals of contemporary Islamic society. It also highlights the role played by Al-Albait and their achievements in building Islamic civilization and preaching the golden mean and tolerance. The university also provides the Arab and Islamic worlds with specialists who are able to present Islamic ideology and civilization in their correct forms away from fanaticism and deviated thinking.

\section{Problem of the Study}

(WISE U.) moved to a new location in 2012 creating new positions and restructuring the system in order to comply with standards of quality assurance and accreditation in Jordan, depending on ergonomics. Several studies like those of As-Sleihat (2011); Al-Suroor \& Az-Zoubi (2009) revealed that there were management problems in Jordanian Universities. Ergonomics in this case plays its role in mitigating the issue and in improving productivity (Evans \& Colliter 2007).

To the researcher's knowledge, no study was conducted about the role of modern changes in mitigating management problem in the university. That was the motive behind tackling the issue of the role ergonomics plays in alleviating management problems in the university from the perspective of staff members.

\section{Question of the Study}

3.1 First question. What is the level of applying ergonomics at (WISE U.) from the perspective of staff members?

3.2 Second question: what is the level of decreasing management problems at (WISE U.) from the perspective of staff members?

3.3 Third question: what is the impact of ergonomics in limiting management problems, of which the null hypothesis is an offshoot, on the university? Which the following hypothesis emerges from it: There is no effect with statistical significance at the function level $(a=0.05)$ of ergonomics on limiting management problems in (WISE U.).

\section{Significance of the Study}

Theoretically, the significance of this study stems from what it offers regarding ergonomics and the remedy it provides for management problems being one of the fewest studies conducted at the local level that deals with such an important issue, as far as the researcher knows. The significance also stems from the two questionnaires designed, that of ergonomics and that of remedy, for management problems. The study can be also of benefit for universities and intuitions of education. From the empirical stance, the study could be of help for deans of colleges and chairmen who endeavor to improve the quality of education offered to students, in addition to determining the needs of staff members.

\section{Procedural Definitions of the Terms}

The study included terms and procedures defined as follows:

1. Ergonomics: (Newman, 2005:1) defines it "the science concerned with the interaction between human resources and components of work system, application of concepts and scientific theories, and designs which secure a comfortable and safe life for employees."

Procedure wise: it is reorganizing human resources in (WISE U.) to ensure harmony and coordination between competent people and the works assigned for them.

Evaluating the extent of application can be figured out through the score the staff member gains on ergonomics questionnaire set for the purpose of this study.

2. Management problems: these are the problems related to management duties as manifested in deactivation of administrative system or in inability to perform its duties and achieve its goals, or when the administration situation doesn't comply to the case whether in the present or future, or whenever any necessity emerges to change the goals of the administration (Shams Eddin, 2005:11). 
Procedure wise, it is defined as an internal or external case in the management system that hampers achieving the goals, partially or totally at (WISE U.). It was measured through the score the staff member gets on the questionnaire of problem-solving set for this study.

\section{Limitations of the Study}

General results of this study are confined to the following:

1. Human limitation: study instruments were applied to (94) staff members at (WISE U.)

2. Place limitation: (WISE U.), Amman, Jordan.

3. Time limitation: The second semester of the academic year 2018/2019.

Results will be verified for validity and reliability through serious respondents.

\section{Methodology of the Study}

The researcher used the descriptive method which describes the education phenomenon as it really is. It is illustrated quantitatively in order to come up to conclusions that help understand reality through analysis of results.

\section{Population of the Study and Its Sample}

The population of the study comprises all staff members of (WISE U.) whose number amounts to (252) and distributed among (12) faculties of the university. (112) members who represent $44 \%$ were randomly selected, using the cluster random excel file. They were given the questionnaires of which (97) were accepted and three rejected. Thus, the net total was (94).

\section{Instruments of the Study}

The researcher used two questionnaires: one on ergonomics and the other on the treatment of management problems which might be described as follows

\subsection{Ergonomics Questionnaire}

The researcher designed the ergonomics questionnaire relying on some studies, like those of Abu Awad (2015), and Khan (2015), where he quoted modified, and added some paragraphs that suit staff members then elicited their validity and reliability.

\subsection{Questionnaire of Management-Problem Treatment}

The researcher designed a questionnaire for the treatment of management problems relying on some studies, like those of Al-Amiri (2014) and Al-Yusuf (2012), where he quoted, modified, and added some paragraphs that suit staff members then elicited their validity and reliability.

\subsection{Validity of Questionnaires}

To verify the validity of the two instruments of the study, the researcher presented them to a panel of specialized and experienced staff members at (WISE U.) and Jordan university for arbitration. Their observations and suggestions were taken into consideration. Ergonomics questionnaire ended up with (37) items divided into four dimensions: human, included (10) items, structural (10) items, technical (9), and performance assessment (8) items. The questionnaire of treatment problems ended up with (25) items, both of which were designed according to Leikar's fivefold scale. All items were positive.

\subsection{Reliability of Instruments of the Study}

To verify the reliability of the questionnaire, the researcher calculated the internal uniformity of expressions using Cronbach Alpha equation after being applied to a pioneer sample of (22) staff members from the following universities: Jordan, Yarmouk, and Jarash outside, the study sample. The validation coefficients for the ergonomics questionnaire ranged between $(0.89-0.83)$, the total score was $(0.91)$; while the validity coefficient of the internal uniformity according to Kronbach Alpha's equation for treatment of management problems was $(0.81)$.

The two questionnaires were designed in a way to enable staff members assess the levels of ergonomics and problem treatment at (WISE U.) from their perspective according to Leikart's fivefold scale as follows: very high; 5 points; high, 4; medium, 3; low, 2, very low, 1, point. The following statistical gradation was used to evaluate the levels of arithmetic means: $(1,00-2,23)$ of low applicability; $(2,34-3,67)$ medium, and finally $(5,00-3$, 68) High.

\section{Statistical Analyses}

In answering the questions, the study relied on the following statistical analyses: 
1. Arithmetic means and standard deviations were adopted to assess the levels of ergonomics and management problems.

2. Simple linear regression was used to detect the influences of ergonomics on the treatment of management problems from the perspective of staff members at (WISE U.)

\section{Results of the Study}

Study results and interpretation of the first question: what is the level of applying ergonomics at (WISE U.) from the perspective of staff members?

11.1 In answering this question, arithmetic means and standard deviations of the study for all dimensions of ergonomics were calculated: results are presented in table (1)

Table (1). Arithmetic means and deviation standards for ergonomic dimensions

\begin{tabular}{lllll}
\hline Dimension & $\begin{array}{l}\text { Arithmetic } \\
\text { mean }\end{array}$ & $\begin{array}{l}\text { Standard } \\
\text { deviation }\end{array}$ & Rank & Score \\
\hline Human & 3.50 & 0.61 & 2 & Medium \\
Structural & 3.50 & 0.54 & 2 & Medium \\
Technical & 3.47 & 0.47 & 3 & Medium \\
$\begin{array}{l}\text { Performance Assessment } \\
\text { Total }\end{array}$ & 3.51 & 0.76 & 1 & Medium \\
& 3.50 & 0.40 & - & Medium \\
\hline
\end{tabular}

Table (1) Shows that the evaluation of (WISE U.) regarding the application of ergonomics in the university was medium. Its arithmetic mean was (3.50) and the standard deviation was $(0.40)$; performance assessment rated first with an arithmetic mean (3.51) and a standard deviation (0.76) with medium score; the human and structural dimensions rated second with an arithmetic mean (3.50) and a standard deviation $(0.61),(0.54)$ consecutively with a medium score. The technical dimension rated last with an arithmetic mean (3.47) and a standard deviation (0.47) with medium score.

The reason behind the medium score is because staff members see that ergonomics in the university gives performance assistance priority of concentration, in addition to the interest it gives to human resources to achieve distinction among other universities. The technical dimension came last being available in the university by which it copes with accelerating technological development.

The nature of administrative work in universities doesn't require much of technology because the work basically depends on internet, computers, printers and intranet. In addition, most of staff members works are just technical ones related to teaching and scientific research.

Arithmetic means, standard deviations and scores for the items including ergonomics are presented in detail as follows:

11.1.1 Human Dimension

Table (2). Arithmetic means, standard deviations, ranks, and scores of items of human dimension

\begin{tabular}{lllllc}
\hline No. & Human dimension & Arithmetic mean & $\begin{array}{l}\text { Standard } \\
\text { deviation }\end{array}$ & Rank & Score \\
\hline 1 & $\begin{array}{l}\text { The administration works on } \\
\text { rethinking and discarding routine }\end{array}$ & 3.59 & 0.66 & 1 & Medium \\
2 & $\begin{array}{l}\text { Employees have a clear vision about } \\
\text { objectives and results of ergonomics }\end{array}$ & 3.46 & 0.83 & 7 & Medium \\
\hline
\end{tabular}




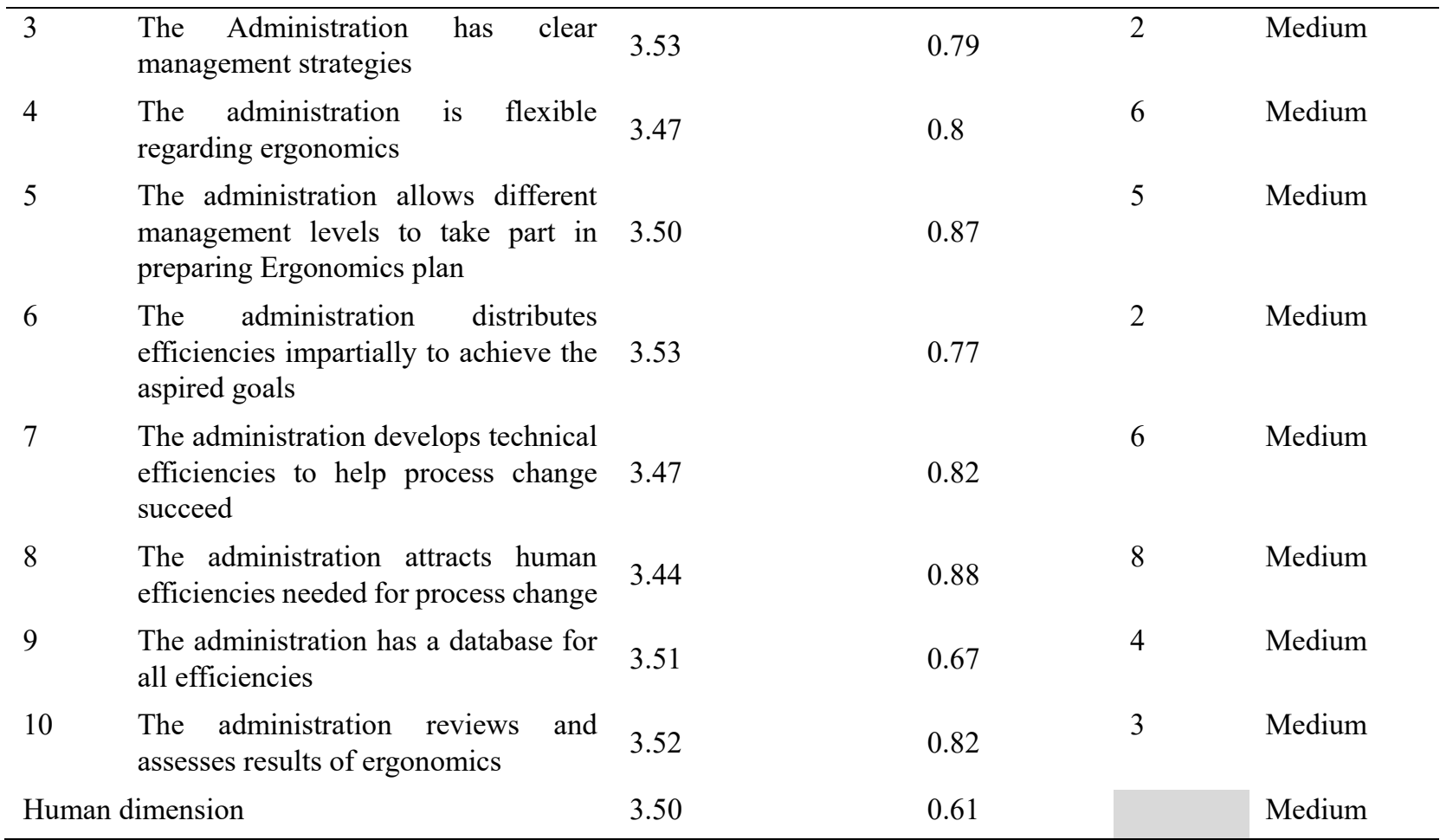

Table No. (2) Shows that the arithmetic means for the answers of staff members regarding the item of human dimension in the ergonomics questionnaire ranged between (3.44 - 3.59) and all items scored medium. The item stating "the administration works on rethinking and discarding routine" rated first with an arithmetic mean (3.59) and a standard deviation (0.66); while "the administration attracts necessary human efficiencies for the change process item" came last with an arithmetic mean (3.44) and a standard deviation (0.88).

Such responses may be attributed to the fact that (WISE U.) is a relatively a new university in Jordan rapidly developing and basically depending on human resources for modernization and development. Its management cadre and staff members have a relatively good management experience.

\subsubsection{Structural Dimension}

Table (3). Arithmetic means, standard deviations ranks, and score of items on the structural dimension

\begin{tabular}{llllll}
\hline NO & Structural dimension & $\begin{array}{l}\text { Arithmetic } \\
\text { mean }\end{array}$ & $\begin{array}{l}\text { Standard } \\
\text { deviation }\end{array}$ & Rank & Score \\
\hline 11 & $\begin{array}{l}\text { The developed organized structural helps to } \\
\text { accomplish management tasks }\end{array}$ & 3.64 & 0.73 & 2 & Medium \\
\hline $\begin{array}{l}\text { The administration works in compliance } \\
\text { with a clear organized structure } \\
\text { The change in the structure copes with }\end{array}$ & 3.48 & 0.71 & 6 & Medium \\
\hline $\begin{array}{l}\text { strategy changes of management } \\
14\end{array}$ & 3.22 & 0.88 & 9 & Medium \\
$\begin{array}{l}\text { Changes in the structure contribute to } \\
\text { distinguished services }\end{array}$ & 3.32 & 0.77 & 8 & Medium \\
\hline
\end{tabular}


15 The modified organizational structure helps in developing employees performance

\subsection{8}

16

Positions in the structure cover all management needs

17 Organizational structure helps reengineer administration processes

18 The structure of the administration copes with general objectives

19 Flexibility of the structure helps in dealing with crises when they occur

20

Administrative jobs have clear job descriptions

Structural dimension

\subsection{5}

3.61

3.54

3.55

3.61

3.50
7

Medium

0.80

1

Medium

0.80

3

Medium

0.69

5

Medium

0.80

4

Medium

0.74

3

Medium

0.81

054

Medium

Table No. (2) Shows that the arithmetic means of staff members answers at regarding the structural dimension ranged between $(3.22-3.65)$ and scores of all items were medium. The item "all jobs on the structural frame cover all management tasks" rated first with an arithmetic mean (3.65) and a standard deviation (0.80). As for the item "change copes with the structural changes of management strategy", it rated last with an arithmetic mean (3.22) and standard deviation (0.88).

These responses may be attributed to the fact that (WISE U.) changed its location and moved to a new campus creating new management jobs that cover all requirements of university and administrative works. It examined work needs for new jobs to make work move smoothly in compliance with the nature of the new campus, in addition to developments of administration and university needs.

\subsubsection{The Technical Dimension}

Table (4). Arithmetic means, standard deviations, ranks, and score of the technical dimension

\begin{tabular}{|c|c|c|c|c|c|}
\hline No & Technical dimension & $\begin{array}{l}\text { Arithmetic } \\
\text { mean }\end{array}$ & $\begin{array}{l}\text { Standard } \\
\text { deviation }\end{array}$ & Rank & Score \\
\hline 21 & $\begin{array}{l}\text { Administration depends on suitable technology } \\
\text { for change }\end{array}$ & 3.56 & 0.74 & 3 & Medium \\
\hline 22 & $\begin{array}{l}\text { Technological development encourages } \\
\text { administration to adopt re-ergonomics }\end{array}$ & 5.57 & 0.77 & 2 & Medium \\
\hline 23 & $\begin{array}{l}\text { Computer programs for all necessary functions } \\
\text { are available }\end{array}$ & 3.52 & 0.72 & 4 & Medium \\
\hline 24 & $\begin{array}{l}\text { Administration uses computers for internal and } \\
\text { external transactions }\end{array}$ & 3.49 & 0.95 & 5 & Medium \\
\hline 25 & $\begin{array}{l}\text { Available technology helps administration in } \\
\text { decision making }\end{array}$ & 3.31 & 0.89 & 6 & Medium \\
\hline 26 & $\begin{array}{l}\text { There is an incessant search for the best } \\
\text { technological methods to make ergonomics a } \\
\text { success }\end{array}$ & 3.26 & 0.89 & 8 & Medium \\
\hline 27 & $\begin{array}{l}\text { Availability of information and data makes it } \\
\text { easy to deal with them }\end{array}$ & 3.57 & 0.85 & 2 & Medium \\
\hline
\end{tabular}




\begin{tabular}{llllll}
\hline 28 & $\begin{array}{l}\text { Technology contributes to the redesign of } \\
\text { management processes }\end{array}$ & 3.68 & 0.82 & 1 & High \\
$29 \begin{array}{l}\text { Available technology decreases effort and saves } \\
\text { time }\end{array}$ & 3.27 & 0.89 & 7 & Medium \\
Technical dimension & 3.47 & 0.47 & & Medium \\
\hline
\end{tabular}

Table No. (4) Shows that the arithmetic means of staff members answers at (WISE U.) on items of technical dimension ranged between $(3.26$ - 3.68). The item "technology contributes to redesign management processes" rated first with an arithmetic mean (3.68), a standard deviation (0.82), and high score. As for the item "there is an incessant search for the best technological methods to make ergonomics succeed", it rated last with an arithmetic mean (3.26), a standard deviation (0.89), and medium score.

This result is interpreted to be the outcome of (WISE U.) endeavors for competition and modernization of technological methods which it has recently started, but still at the stage of checking results of modernization.

11.1.4 Dimension of Performance Assessment

Table (5). Arithmetic means, standard deviations, and ranks for the dimension of performance assessment

\begin{tabular}{llllll}
\hline No & Performance assessment & $\begin{array}{l}\text { Arithmetic } \\
\text { mean }\end{array}$ & $\begin{array}{l}\text { Standard } \\
\text { deviation }\end{array}$ & Rank & Score \\
\hline 30 & $\begin{array}{l}\text { There is a regular assessment for } \\
\text { performance }\end{array}$ & 3.57 & 0.92 & 2 & Medium \\
31 & $\begin{array}{l}\text { Assessment mechanisms deal with all } \\
\text { levels of structural organizing of } \\
\text { management } \\
\text { There is a follow-up for assessment } \\
\text { results to develop performance }\end{array}$ & 3.55 & 5 & Medium \\
33 & $\begin{array}{l}\text { There are indications of measuring } \\
\text { performance }\end{array}$ & 3.57 & 0.91 & 4 & Medium \\
34 & $\begin{array}{l}\text { Reviewing modified plans is based on } \\
\text { performance results } \\
35\end{array}$ & 3.45 & 0.91 & 2 & Medium \\
\hline 36 & $\begin{array}{l}\text { Methods used in performance } \\
\text { Essessment cope with its goals }\end{array}$ & 3.38 & 0.92 & 6 & Medium \\
37 & $\begin{array}{l}\text { into consideration } \\
\text { Ergonomics concentrates on developing } \\
\text { job performance }\end{array}$ & 3.45 & 0.91 & 8 & Medium \\
Performance assessment & 3.51 & 0.99 & 6 & Medium \\
\hline
\end{tabular}

Table No. (5) Shows that, after assessment, the arithmetic means of answers of staff members at (WISE U.) ranged between $(3.38-3.62)$ and results of all items were medium. The items "ergonomics takes employees capabilities into consideration" rated first with arithmetic mean (3.62) and standard deviation (0.99). As for the item "methods used in performance assessment cope with its goals", it rated last with arithmetic mean (3.88) and standard deviation (0.91).

These responses can be viewed through the perspective that, like other universities, (WISE U.) aims to improve performance by controlling, evaluating, and activating job performance by determining the proper indication for each job in the light of those indications.

11.2 Results related to the second question "what is the level of decreasing management problems at (WISE U.) from the perspective of staff members?

To answer this question, arithmetic means and standard deviations of the management questionnaire for members of the sample were calculated. The results are presented in table No. (6). 
Table (6). Arithmetic means, standard deviations, ranks, and scores of items on the treatment of management problems

\begin{tabular}{|c|c|c|c|c|c|}
\hline No & Treatment of management problems & $\begin{array}{l}\text { Arithmetic } \\
\text { mean }\end{array}$ & $\begin{array}{l}\text { Standard } \\
\text { deviation }\end{array}$ & Rank & Score \\
\hline 1 & $\begin{array}{l}\text { The university endeavors to develop its programs to } \\
\text { comply with quality assurance }\end{array}$ & 4.59 & 0.65 & 1 & High \\
\hline 2 & The university diversifies sources of knowledge & 4.13 & 0.57 & 11 & High \\
\hline 3 & $\begin{array}{l}\text { The university adopts an objective evaluation for staff } \\
\text { members }\end{array}$ & 4.24 & 0.77 & 4 & High \\
\hline 4 & $\begin{array}{l}\text { The university encourages staff members to participate } \\
\text { in seminars and academic conferences }\end{array}$ & 3.99 & 0.71 & 23 & High \\
\hline 5 & $\begin{array}{l}\text { The university encourages socialization and interaction } \\
\text { among staff members }\end{array}$ & 4.16 & 0.76 & 9 & High \\
\hline 6 & $\begin{array}{l}\text { University activities consolidate interaction between } \\
\text { staff members and students }\end{array}$ & 4.04 & 0.75 & 19 & High \\
\hline 7 & $\begin{array}{l}\text { Mutual concordance is present between administration } \\
\text { and academicians }\end{array}$ & 4.20 & 0.77 & 6 & High \\
\hline 8 & $\begin{array}{l}\text { The university helps to improve coordination between } \\
\text { faculties and academic departments }\end{array}$ & 4.04 & 0.77 & 18 & High \\
\hline 9 & The university always modernizes its plans & 4.04 & 0.81 & 17 & High \\
\hline 10 & The university modernizes methods of teaching & 3.95 & 0.75 & 25 & High \\
\hline 11 & $\begin{array}{l}\text { The university helps staff member, develop his } \\
\text { efficiency }\end{array}$ & 4.07 & 0.80 & 16 & High \\
\hline 12 & $\begin{array}{l}\text { The university helps to improve students' level of } \\
\text { knowledge }\end{array}$ & 3.98 & 0.77 & 24 & High \\
\hline 13 & The university meets the needs of staff members & 4.35 & 0.66 & 2 & High \\
\hline 14 & University laws control students' absences & 4.29 & 0.75 & 3 & High \\
\hline 15 & The university urges staff members to do research & 4.20 & 0.68 & 7 & High \\
\hline 16 & $\begin{array}{l}\text { the university provides students with chances to do } \\
\text { research }\end{array}$ & 4.20 & 0.76 & 8 & High \\
\hline 17 & $\begin{array}{l}\text { The university correlates pre- university learning with } \\
\text { that of university }\end{array}$ & 4.22 & 0.69 & 5 & High \\
\hline 18 & $\begin{array}{l}\text { The university develops communication through social } \\
\text { media }\end{array}$ & 4.16 & 0.81 & 10 & High \\
\hline 19 & The university activates its laws of control & 4.07 & 0.73 & 10 & High \\
\hline 20 & $\begin{array}{l}\text { The university encourages academic communication } \\
\text { between its staff members and their counterparts in } \\
\text { other universities }\end{array}$ & 4.12 & 0.79 & 12 & High \\
\hline 21 & The university ensures job security for staff members & 4.02 & 0.79 & 20 & High \\
\hline 22 & $\begin{array}{l}\text { university administration allows staff members to share } \\
\text { in decision making }\end{array}$ & 3.99 & 0.82 & 22 & High \\
\hline 23 & $\begin{array}{l}\text { Number of students is pertinent to number of staff } \\
\text { members }\end{array}$ & 4.00 & 0.81 & 21 & High \\
\hline 24 & $\begin{array}{l}\text { The university assigns works that suit staff member } \\
\text { specialization }\end{array}$ & 4.09 & 0.83 & 14 & High \\
\hline 25 & The university invents methods to break routine work & 4.12 & 0.75 & 13 & High \\
\hline \multicolumn{2}{|r|}{ Treatment of management problems } & 4.13 & 0.47 & & High \\
\hline
\end{tabular}

Table No. (6) Shows the arithmetic means of staff members' answers at (WISE U.) regarding the variable item of problem treatment ranged between $(3.98-4.59)$. All items scored high. The item "the university endeavors to develop its programs to cope with quality assurance" rated first with an arithmetic mean (4.59) and a standard variation (0.65). As for the item "the university modernizes its methods of teaching, it rated last with an arithmetic mean (3.95) and a standard deviation (0.75).

Such responses might be interpreted in that (WISE U.), through such modernizations and development which influenced all aspects of administrative work, the university endeavors to maintain its position among Jordanian 
universities and to meet the criteria of accreditation in Jordan.

11.3 Results pertaining the third question "what is the effect of ergonomics on decreasing management problems at (WISE U.)?

In answering this question, the following were conducted:

A. Normal distribution test: to ensure that the study sample doesn't include extremist values and were fairly distributed, two tests were adopted: (Kolmogorov - Smirov and Shapiro - Wilk tests). It was assured that the variable follows the normal distribution if the function value (sig) was higher than 0.05 .

B. Study hypothesis test: study hypothesis, "there are no effects with statistical significance at the function level $(a=0.05)$ for ergonomics in decreasing management problems at (WISE U.). By checking them using the multiple linear regression analysis, the results were as presented in table No. (7):

Table (7). Results of multiple linear regression regarding the influence of ergonomics in the treatment of management problems at (WISE U.)

\begin{tabular}{lllllll}
\hline & & \multicolumn{2}{l}{ Summary model } & ANOVA & & \\
\cline { 2 - 6 } Dependent variable & $\begin{array}{l}\text { R } \\
\text { Restricti } \\
\text { on } \\
\text { Coefficie }\end{array}$ & $\begin{array}{l}\text { Restrict } \\
\text { coefficient }\end{array}$ & Found & $\begin{array}{l}\text { Degree } \\
\text { freedom }\end{array}$ & of Sig F & \\
$\begin{array}{l}\text { Treatment of management } \\
\text { problems }\end{array}$ & 0.333 & 0.111 & 6.591 & $4-93$ & 0.000 \\
\hline
\end{tabular}

Results of this table show that the restriction coefficient is $(\mathrm{R}=0.333)$ which implies a positive relation between independent and dependent variables. The $(\mathrm{F})$ value (6.591) at the function level (sig $\mathrm{F}=0.000$ ) reflects the rejection of the Null hypothesis and acceptance of an alternative hypothesis. This reflects an influence of the independent variable (ergonomics) on the dependent one (treatment of management problems). The restriction value $(\mathrm{R} 2=0.111)$ shows that $(11.1 \%)$ of the difference in treating management problems might be interpreted through the difference in ergonomic dimensions.

To determine which of the dimensions (human, structural, technical, or performance assessment) play an influential role in the treatment of management problems, the coefficient of standard regression and statistical value (t) was elicited as presented in table No. (8).

Table (8). Standard and non-standard regression dimensions of ergonomics, coefficients in treating management problems at (WISE U.)

\begin{tabular}{lllll}
\hline Coefficients & & & & \\
\hline Statement & $\beta$ & Mean error & $\mathrm{T}$ & Sig t \\
Human dimension & 0.184 & 0.061 & 3.002 & 0.003 \\
Structural dimension & 0.139 & 0.068 & 2.037 & 0.043 \\
Technical dimension & -0.023 & 0.068 & -0.339 & 0.735 \\
Performance assessment dimension & -0.096 & 0.043 & -2.247 & 0.026 \\
\hline
\end{tabular}

Table No. (8) shows that $(\beta)$ value of the human dimension was $(0.184)$ and $(t)$ value was $(3.002)$ with a function level $(\operatorname{sig}=0.003)$.

This implies that the human dimension is incorporeal. The $(\beta)$ value of the structural dimension was $(0.139)$ and (t) value (2.037) with a function level (sig- 0.043 ) which implies that the effect of the structural dimension was incorporeal.

The $(\beta)$ value of the technical dimension was $(-0.023)$ and $(t)$ value $(-0.339)$ with a function level $(\operatorname{sig}=0.735)$ which implies that the technical dimension doesn't play any role in management - problem treatment. The $(\beta)$ 
value of the performance assessment was $(-0.069)$ and $(t)$ value $(2.247)$ with a function level (sig $=0.026)$ which implies that the dimension of performance assessment influences treatment of management problems at (WISE U.).

This result may be caused by the ergonomics dimension which is responsible for solving and mitigating the problems. It is the first element to be affected by management problems in the university. Thus, the major goal of ergonomics is to utilize the human source and put it in the suitable position and that makes management move smoothly reducing the problems that might emerge in the university.

Management planning rests on checking the task then organizing procedures accordingly. The nature of management tasks at (WISE U.) concentrates on offering high quality education services as this dimension facilitates students' services and solves management problems which provide the university a competitive position among other universities in Jordan.

This result may be attributed to the fact that (WISE U.) mainly depends on information technology in serving students. This technology consists mainly of networks, computers, printers and database centers. Having specialists in this field in the university makes it easier to provide such services. This field doesn't help much in decision making, restructuring, and in decreasing management burden and subtasks because it is more of organizing than contributing to problem solving.

This result of assessing performance dimension at (WISE U.) may be attributed to the fact that the university caters for productivity and service quality, in addition to performance assessment per se. This makes staff members work hard to avoid any shortage from which a problem might emerge.

Due to the job description the university adopts, it makes it easier to detect any flaw in performance assessment for each staff member or employee.

\section{Recommendations}

In the light of results of the study, the researcher recommends the following:

- Activating the role of technical dimension in solving management problems

- Attracting professionals in ergonomics making use of experiences of other universities

- Adjusting aims of change in structural order to cope with strategy changes in the university

- Searching for technological methods to make ergonomics a success

- Adopting assessment objectives starting with performance assessment

\section{References}

\section{Arabic references}

Abu Awad, R. (2015). Real application of human resources and its relation to job performance at the general employee bureau in Gaza Strip. Unpublished thesis, Al-Aqsa University, Palestine.

Al Duri, Z. (2003). Management strategy. Baghdad University, Iraq.

Al-Ali, M. (2004). Applying principles of ergonomics with regard to labor system design in accordance with specifications of international standards (ISO: 6385 \& ISO: 10075): a case study of general companies for electrical industries. Unpublished dissertation, Al-Mustansireyah University, Iraq.

Al-Ameri, A. H. (2014). Problems staff members encounter, from their perspective, in colleges of education in Yemen Universities. Journal of Social Studies, 14, 37-62.

Al-Juburi, A. K. (2007). Successful manager. Beirut: Dar Al-Tyseer and Dar Al-Bihar.

Al-Muzyen, S. (2015). the status of academic and management problems and ways of decreasing them from the perspective of staff members of Gaza Islamic university. Journal of Al-Quds Association for Islamic studies, $3(2), 32-59$.

Al-Nueimi, J. (2006). Developing higher education in Iraq. Arab academy in Denmark.

Al-yusuf, J. (2012). Problems that face staff members at King Salman University. Unpublished M.A thesis, University of Imam Mohammed Ibn Saud, Saudi Arabia.

Ash-Shammari, T. (2005). Management and technical problems that encounter female principles of public schools in Hael from the perspective of principles, supervisors, and educators. Unpublished M.A thesis, King Saud University. 
As-Salem, M. (2000). Integration between strategic planning and special practices in managing human resources in Arab labor organizations. Proceedings of the conference on human resources management and challenges of the new century. Yarmouk University, Irbid, July 18-21, 2002.

As-Shebli, H., \& An-Sour, M. (2009). Management of contemporary establishment. Amman: Dar Al-Safa for publication and distribution.

As-Sroor, M. H., \& Az-Zoubi, I. A. (2009). Academic problems from the perspective of staff members at Al-Albeit University. Journal of Educational Sciences, 3605, 231-251.

As-Sultan, F. (2001). Re-engineering of theoretical and practical work system: Creative leadership in confronting contemporary challenges. Second Arab conference, Cairo: Egypt.

At-Taei, O. (2015). Management problems that face academic chairmen in colleges of Baghdad and Mustansireyah Universities and suggested solutions. Unpublished M.A thesis, Baghdad University, Iraq.

Dagher, A., \& Al-Qudah, H. (2016). A human engineering model of decision making of education in Jordanian Universities. Journal of Educational Sciences, 43(2), 781-803.

Farhat, G. (2011). The role of re-engineering as a method of change in present environmental conditions. A research paper read in the international scientific forum on creativity and organizational change in modern organizations: A study and analysis: national and international experiences. 2/2011/ Dali Ibrahim University, Algeria.

Khan, A. (2012). Re-engineering of processes as an introduction to excellence of human resource. Management and Economic Studies, 12. Baskara University, Algeria.

Khan, A. (2015). The importance of re-ergonomics in improving human performance in the economic establishment. Unpublished dissertation. Mohammed Khaider University: Baskara, Algeria.

Mahmoud, S. (2013). The role of some factors of ergonomics in absorbing jobs: A pioneer study of the attitude of an employee sample in Assaseel company for communication. M.A unpublished thesis, Suleimaniyeh University, Iraq.

Radwan, M. (2008). Procedures re-engineering. Paper presented in a seminar on improving government departments.

Shams, E. A. (2005). Introduction to theory of problem analysis and management decision taking. Center of developing productive management, Damascus, Syrian Arab Republic.

\section{Foreign References}

Enserm, M., Moorthy, K., \& Setegn, D. (2013). Assessing the effect of business process reengineering performance: A case study of bureau of finance and economic development (BoFED), Oromia Regional State, Ethiopia. International Refereed Research Journal, 4(1), 115-123.

Erraha, B., Oubedda, L., \& Khalfaoui, M. (2012). Data intelligent analysis for decision-making at universities. Published by Canadian Center of Science and Education. Computer and Information Science, 4(5), 19138989.

Evans, J., \& Collier, D. (2007). Operation management: an integrated goods and services approach (7th ed.). Thomson South-Western, Australia.

Gmelch, W., \& Parkey, F. (1999). Becoming a department chair. negotiation the transition from scholar administrator. Eric, ED: 430493.

Kumru, M., \& Kihcogulari, P. (2008). Process improvement through ergonomic design In welding shop of automotive factory. Department of Industrial Engineering, Dogus University.

Neumann, P. (2005). Ergonomics and effective production systems - moving from reactive to proactive development. Print In Lenanders Tryckeriab, University of Ryerson.

Slack, N., Chambers, S., \& Johnston, R. (2004). Operation management (4th ed.). Print-Hall Inc, U.S.A.

\section{Copyrights}

Copyright for this article is retained by the author(s), with first publication rights granted to the journal.

This is an open-access article distributed under the terms and conditions of the Creative Commons Attribution license (http://creativecommons.org/licenses/by/4.0/). 